
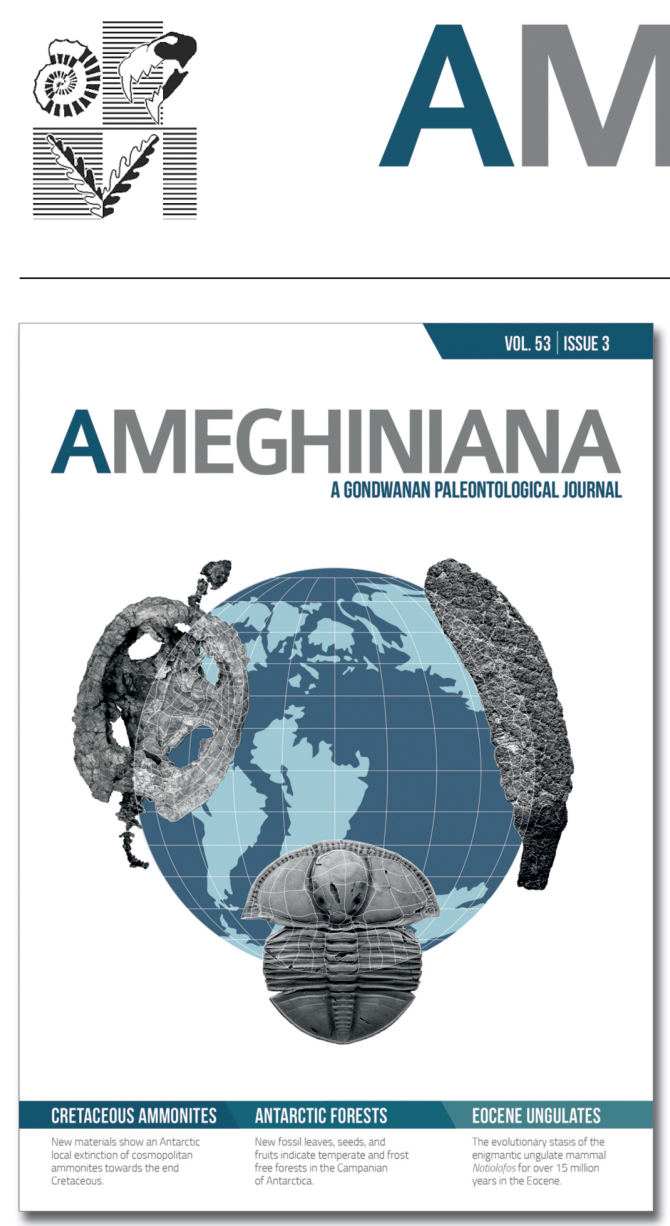

\title{
NEW UPPER CRETACEOUS \\ (CAMPANIAN) FLORA FROM \\ JAMES ROSS ISLAND, \\ ANTARCTICA
}

ARI IGLESIAS

Instituto de Investigaciones en Biodiversidad y Medio Ambiente, CONICET- Universidad Nacional del Comahue, Quintral 1250, R8400FRF San Carlos de Bariloche, Río Negro, Argentina.

Submitted: June $30^{\text {th }}, 2015$ - Accepted: February $17^{\text {th }}, 2016$

To cite this article: Ari Iglesias (2016). New Upper Cretaceous (Campanian) flora from James Ross Island, Antarctica. Ameghiniana 53: 358-374.

To link to this article: http://dx.doi.org/10.5710/AMGH.17.02.2016.2930

PLEASE SCROLL DOWN FOR ARTICLE

Also appearing in this issue:

\section{CRETACEOUS AMMONITES}

New materials show an Antarctic local extinction of cosmopolitan ammonites towards the end Cretaceous.

\section{ANTARCTIC FORESTS}

New fossil leaves, seeds, and fruits indicate temperate and frost free forests in the Campanian of Antarctica.
EOCENE UNGULATES

The evolutionary stasis of the enigmantic ungulate mammal Notiolofos for over 15 million years in the Eocene. 


\title{
NEW UPPER CRETACEOUS (CAMPANIAN) FLORA FROM JAMES ROSS ISLAND, ANTARCTICA
}

\author{
ARI IGLESIAS
}

Instituto de Investigaciones en Biodiversidad y Medio Ambiente, CONICET- Universidad Nacional del Comahue, Quintral 1250, R8400FRF San Carlos de Bariloche, Río Negro, Argentina.ari_iglesias@yahoo.com.ar

\begin{abstract}
I present a diverse previously unrecorded assemblage of leaves, cuticle, seeds and fruits from early-mid Campanian marine sediments, representing the first well-preserved macrofloristic record found in the Santa Marta Formation (north of James Ross Island, Antarctica). This new flora is diverse and consistent with the presence of forests under temperate and frost free climate; taxa include: a cycad (Zamiaceae), conifers (Araucaria, Araucarites, Brachyphyllum, and Pagiophyllum), several ferns (including Pteridaceae and ?Schizaeaceae) and angiosperms (including ?Cunoniaceae and Lauraceae). This record helps further our understanding of the vegetation of continental areas in the Antarctic Peninsula during the Late Cretaceous.
\end{abstract}

Key words. Angiosperm. Antarctica. Campanian. Cretaceous. Fossil leaves. Paleobotany.

Resumen. NUEVA FLORA DEL CRETÁCICO SUPERIOR (CAMPANIANO) EN LA ISLA JAMES ROSS, ANTÁRTIDA. Presento una diversa asociación previamente no registrada de hojas, semillas y frutos, en sedimentos marinos del Campaniano temprano-medio, representando el primer registro macroflorístico bien preservado en la Formación Santa Marta (norte de la isla James Ross, Antártida). La flora es consistente con la presencia de bosques bajo clima templado libres de heladas, incluyendo: una cycadal (Zamiaceae), coníferas (Araucaria, Araucarites, Brachyphyllum y Pagiophyllum), varios helechos (incluyendo Pteridaceae y ?Schizaeaceae) y angiospermas (incluyendo ?Cunoniaceae y Lauraceae). Este registro incrementa el conocimiento de la vegetación en áreas continentales de la Península Antártica durante el Cretácico Tardío.

Palabras clave. Angiospermas. Antártida. Campaniano. Cretácico. Hojas fósiles. Paleobotánica.

GEOLOGICAL and paleontological evidence testifies to Antarctica being free of permanent ice during the Mesozoic and early Paleogene (e.g., Birkenmajer and Zastawniak, 1989; Huber et al., 1995; Dutra and Batten, 2000; Miller et al., 2005; Poole et al., 2003). At this time, although climatic conditions may have been more favorable for vegetation development at high paleolatitudes, the long periods of winter darkness alternating with long photoperiods in summers have no analogue in the modern world (Douglas and Williams, 1982; Pirrie and Marshall, 1990; Falcon-Lang and Cantrill, 2001; Royer et al., 2005). The abundance of fossil material, including large trees, makes Antarctica unique for our understanding of biotas thriving in peculiar polar conditions.

Previous research on Cretaceous plants from the James Ross Island include palynological studies that indicate vegetation comprised by a diverse fern flora alongside conifers such as Araucariaceae, Podocarpaceae and Taxodiaceae (Dettmann and Thomson, 1987; Askin, 1988; Piper, 1988;
Whelanm, 1989; Barreda et al., 1999). Fossil woods recovered from the Santa Marta Formation, show the presence of Atherospermataceae, Cunoniaceae, Winteraceae, Lauraceae, and Monimoniaceae (Poole and Francis, 1999, 2000; Poole et al., 2000a, b; Poole and Gottwald, 2001). Although no studies have found evidence of Nothofagaceae within this basal unit, in Eastern Antarctica they seem to be present since the early Campanian (Askin, 1992; Dutra and Batten, 2000). Few records exist detailing leaf floras from James Ross Island: Hayes (1999) focused on angiosperm leaves preserved in the Hidden Lake (Coniacian) and lower Santa Marta formations and the climatic implications, although descriptions have never been formally published (Hayes et al., 2006; Francis et al., 2008). Recently, Kvaček (2014) described a new fertile Marattiaceae fern frond, and Sakala and Vodrážka (2014) described a new species of the angiosperm Antarctoxylon, both from the Hidden Lake Formation on northern James Ross Island.

Here we describe a new diverse flora on James Ross Is- 
land comprised of cycads, conifers, ferns and angiosperms from the Santa Marta Formation (early-mid Campanian) based on leaves, cuticle, seeds, and fruits.

\section{MATERIALS AND METHODS}

The Larsen Basin (Macdonald et al., 1988) is located on the continental shelf of north-eastern Antarctic Peninsula (Fig. 1.1). The northern sub-basin, the James Ross Basin (Del Valle et al., 1992), crops out on several summer ice-free islands including James Ross, Vega, Marambio and Snow Hill islands (Fig. 1.2). The Upper Cretaceous lithostratigraphic units in the James Ross Basin have been studied extensively (Elliot, 1988; Macdonald et al., 1988; Crame et al., 1991, 2004, 2006; Del Valle et al., 1992; Riding and Crame, 2002; Whitham et al., 2006; Reguero et al., 2013). For the purposes of this work I follow the stratigraphy provided by Olivero et al. (1986), Scasso et al. (1991), and Olivero (2012) as they correlate well several outcrops on different islands across the basin.

The plant material was found at a new fossil locality, informally named 'Sitio Feliz' (CF), near the San José Pass between the Monolithic Lake and Santa Marta Cove (Fig. 1.3), with all specimens collected from a single plant-bearing bed $\left(63^{\circ} 54^{\prime} 14^{\prime \prime} \mathrm{S} ; 57^{\circ} 54^{\prime} 40^{\prime \prime} \mathrm{W}\right)$. This locality belongs to the upper part of the Beta Member of the Santa Marta Formation in the upper section of the $\mathrm{N}$ sequence (Olivero, 2012) or alternatively the upper section of Lachman Crags Member
(Crame et al., 1991; Pirrie et al., 1997). Sedimentological facies consists of an alternation of thick bioturbated packages of fine-grained, well-sorted sandstones, silty very finegrained sandstones, and mudstones, with abundant plant debris and large tree trunks. Leaves and permineralized wood were found in calcareous concretions from a single thick fossiliferous layer (Fig. 2).

Geological studies interpret the Santa Marta Formation as facies of delta slopes and channel complexes of a progradational deepwater delta system in a marine shelf (Scasso et al., 1991; Olivero, 2012). The fossiliferous level corresponds to the early-mid Campanian, in the ammonite association 5 (kossmaticeratid amonoids: Natalites cf. morenoi and Natalites taylori) of Olivero (1992). McArthur et al. (2000) assigned the lowermost strata of the Santa Marta Formation as Santonian in age based on strontium isotopes $\left({ }^{87} \mathrm{Sr} /{ }^{86} \mathrm{Sr}\right.$ ratio $\left.\sim 0.70745\right)$ whilst Florisbal et al. (2013) described the Lachman Crag Member as early Campanian based on benthic foraminifera evidence. Keating (1992) and Carvalho et al. (2013) described Santonian dinoflagelate cyst palynomorphs in the base of Santa Marta Formation near the Crame Col (Fig. 1.3), which also agrees with an earlymid Campanian age for the plant fossil level.

The fossil flora is preserved in fully marine deposits. Geological and paleontological studies indicate that leaves and trunks were transported from continental areas of the Antarctic Peninsula located to the west (Scasso et al., 1991;

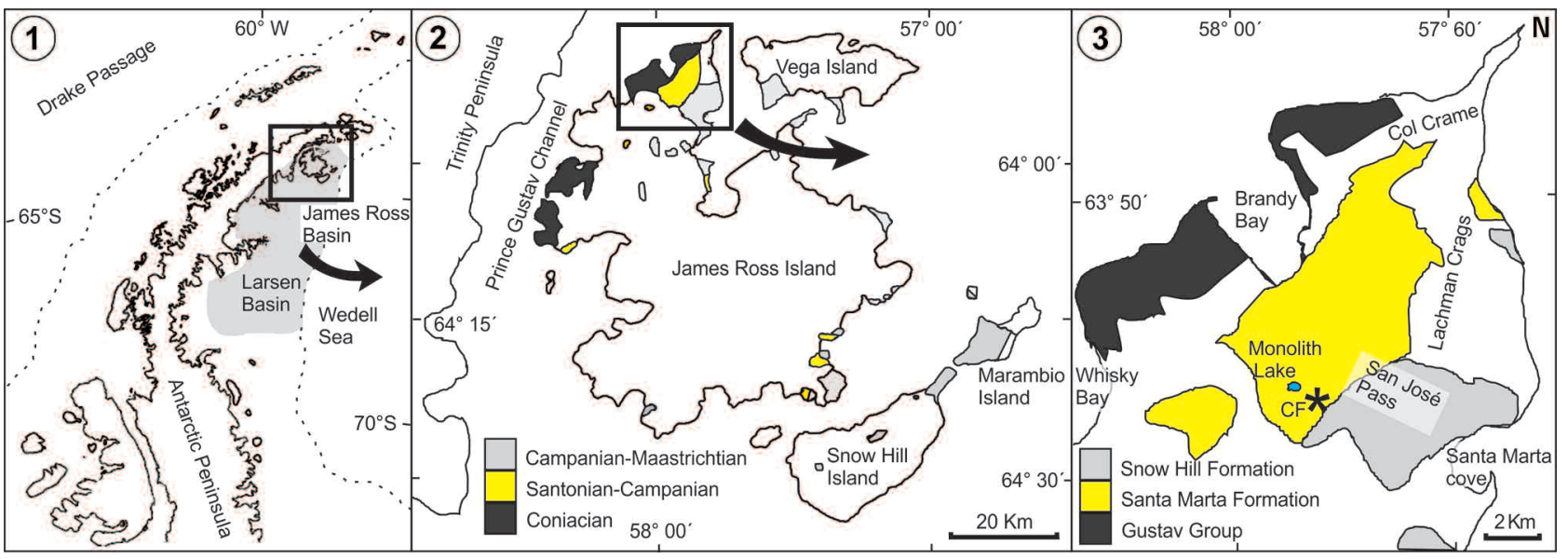

Figure 1. 1, Location and geology, dashed line marking the border of the continental shelf. 2, Upper Cretaceous outcrops in James Ross Basin (Modified from Crame et al., 2004; Olivero et al., 2008; and Olivero, 2012). 3, Fossil locality (asterisk) in the northern James Ross Island (Modified from Carvalho et al., 2013). 


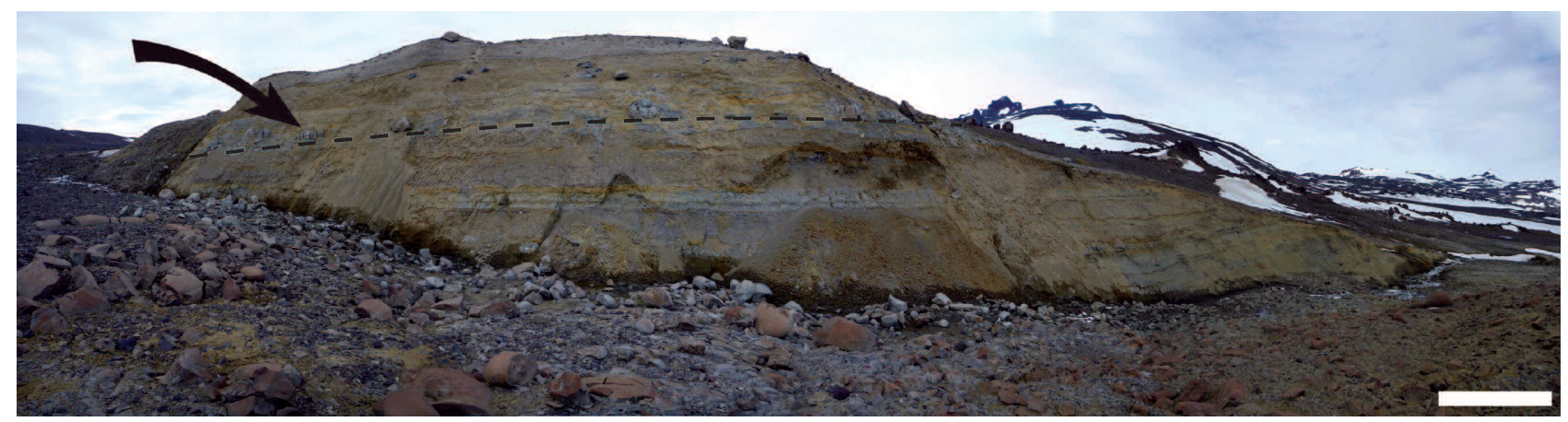

Figure 2. The new fossiliferous outcrop at 'Sitio Feliz' (CF) site near San José Pass, northern James Ross Island. A coarsening and thickening upward sequence, with horizontal strata from a progradational delta system in a marine shelf from Santa Marta Formation (Beta Member from Olivero, 2012). Arrow and dashed line denoting the fossiliferous level containing large calcareous concretions where plant remains were found. Scale bar= $2 \mathrm{~m}$.

Olivero, 2012; Carvalho et al., 2013). The plant material is dominated by angiosperm leaf remains, with fewer conifers and rare occurrences of ferns. The new fossiliferous level also preserves fossil woods. Additional large permineralized logs were sampled close to the plant bearing bed but stratigraphically 10 meters lower (Olivero, 2012). Owing to the fine-grained matrix and early diagenetic cementation with carbonates, many impressions and casts preserve a detailed relief of epidermal and other fine-structural details.

All plant fossils are deposited in the Repositorio Antártico de colecciones paleontológicas y geológicas del Instituto Antártico Argentino (IAA-Pb), San Martín, Buenos Aires, Argentina. Macroscopic images were taken with a Nikon Coolpix 8800 camera under halogen lighting projected at different angles. Cellular and other fine-venation details were analysed and photographed using a Nikon SMZ800 stereoscope with an attached Nikon Digital Sight DS-Fi camera. Image stacking technique was performed using Adobe Photoshop CS5. Cuticles were observed under an Olympus BX50 epifluorescence microscope (long pass green filter).

Angiosperm leaf descriptions follow the standard terminology for leaf architectural descriptions (Hickey, 1973; Hickey and Wolfe, 1975; Ash et al., 1999; Ellis et al., 2009). The leaves were divided into morphotypes following the criteria of Johnson (1989) as revised by Ash et al. (1999) and resultant taxonomy follows that of Smith et al. (2006), Christenhusz et al. (2011), and the Angiosperm Working Group (APG III). For leafy conifer branches the systematics follows that of Heer (1881) and Harris (1969).

\section{SYSTEMATIC PALEONTOLOGY}

Clase PolyPodIOPsIDA (=FILICOPSIDA) Cronquist, Takhtajan, and Zimmermann, 1966

Order Polypodiales Link, 1833

Family PTERIDACEAE Kirchner, 1831

incertae sedis

Leaf Morphotype ANT05

Figures 3.1, 5.6

Studied material. IAA-Pb-20.

Geographic occurrence. 'Sitio Feliz' (CF) locality (63 54' 14" S; $57^{\circ} 54^{\prime} 40^{\prime \prime}$ W), San José Pass, north James Ross Island, Antarctic Peninsula.

Stratigraphic occurrence. Upper section of the Beta Member (lower-mid Campanian) of the Santa Marta Formation (equivalent to the upper section of Lachman Crags Member after Crame et al., 1991).

Description. Pinnate frond. Rachis thin with apparently spiral arrangement of imbricate naked (no laminar projections) pinnae. Pinna small, $2.5 \mathrm{~cm}$ long by $2 \mathrm{~cm}$ wide. Blade cordate in shape with crenate to dentate margin. Teeth $0.5 \mathrm{~mm}$ tall, with rounded sinuses and triangular apex. Base symmetrical, shortly auriculate, concave-convex ending. Pinnae with narrow rachis attachment. No midvein present. Two principal veins arising from the rachis, symmetrically forking near the base. Flavelate principal venation with similar vein thickness. Veins forking and anastomosing in acute angles. Anastomoses more profuse further from the base. Veins 

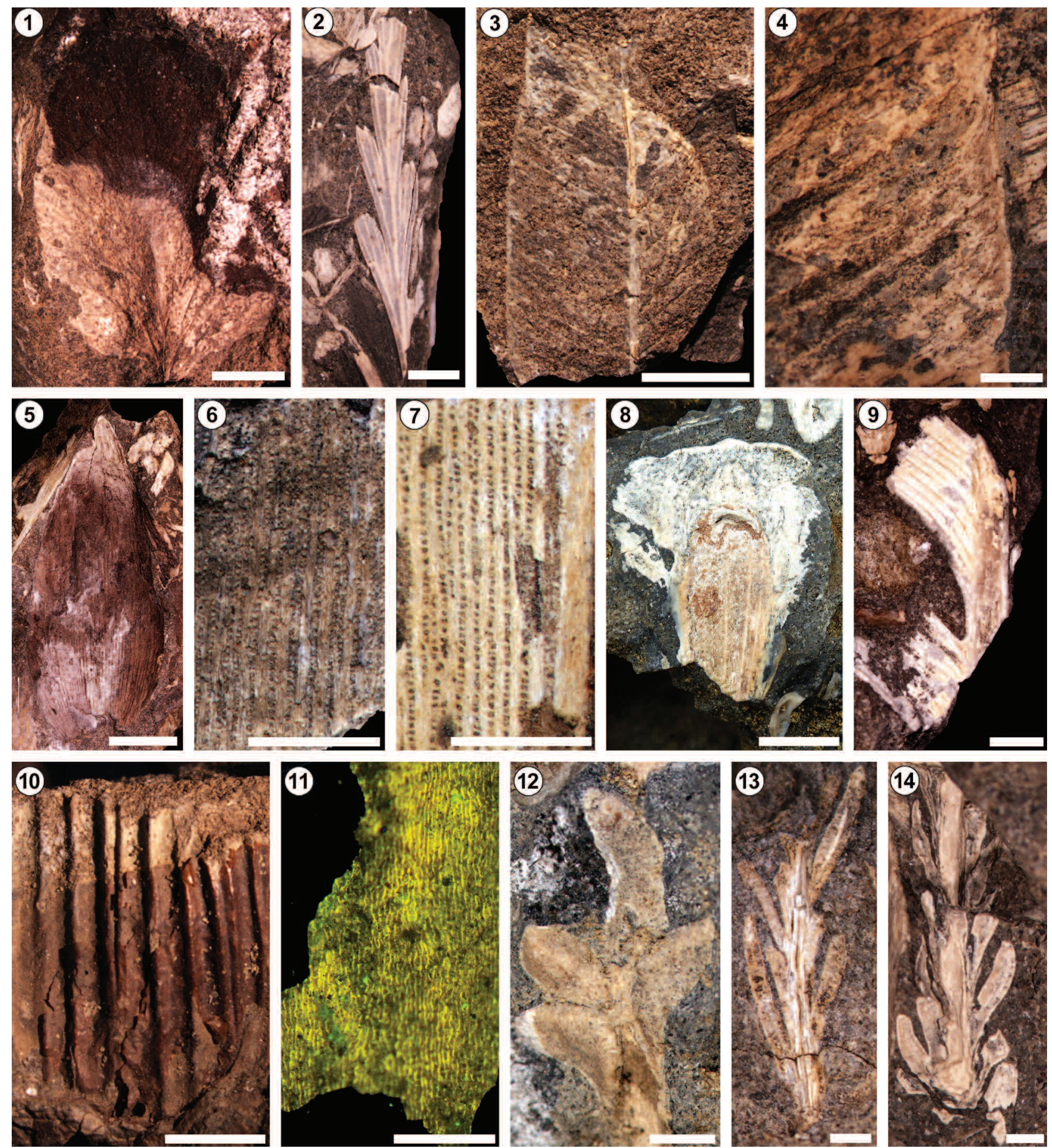

Figure 3. Ferns, conifers, and cycads from Santa Marta Formation (early-mid Campanian), James Ross Island. 1, ANT05 morphotype (IAAPb-20), assigned to Pteridaceae (Polypodiales). 2, ANT08 morphotype (IAA-Pb-38), assigned to ?Schizaeaceae (Schizaeales). 3-4, ANT07 morphotype, Polypodiopsida incertae sedis; 3, IAA-Pb-24; 4, magnified section of IAA-Pb-49 showing collector vein at margin. 5-7, Araucaria fibrosa; 5, IAA-Pb-14; 6, IAA-Pb-27; 7, IAA-Pb-41. 8, Araucarites sp. ovuliferous complex IAA-Pb-45. 9-11, ANT06 morphotype (Zamiaceae, Cycadales); 9, Decurrent pinna and rachis of IAA-Pb-23; 10, IAA-Pb-57 preserving leaf plication and cuticle; 11, cuticular details under epifluorescence, showing festooned epidermal cell walls in IAA-Pb-57. 12, Brachyphyllum sp. 1, IAA-Pb-21. 13, Pagiophyllum sp. 1, IAA-Pb-25. 14, Pagiophyllum sp. 2, IAA-Pb-37. Scale bars $5 \mathrm{~mm}(1,3,8,10) ; 2 \mathrm{~mm}(2) ; 1 \mathrm{~mm}(4,6,7,9,13) ; 10 \mathrm{~mm}(5) ; 0.4 \mathrm{~mm}(11)$. 
reaching teeth apex medially, with strength.

Comments and comparisons. There are many ferns in Pteridaceae that show pinnae with similar vein anastomoses for example Hewardia adiantoides Smith, 1841, Adiantum Linnaeus, 1753, and Lygodium Swartz, 1801 (although Lygodium frequently possesses a midvein). The absence of other cuticular and reproductive characters prevent further comparisons of this morphotype, and is here assigned incertae sedis within Pteridaceae following Smith et al. (2006). There are no other records similar to the ANT05 morphotype described from Antarctica.

Order Schizaeales Schimper, 1869

Family ?SCHIZAEACEAE Kaulfus, 1827

Leaf Morphotype ANT08

Figure 3.2

Studied material. IAA-Pb-28, IAA-Pb-38.

Geographic occurrence. 'Sitio Feliz' (CF) locality $\left(63^{\circ} 54^{\prime} 14^{\prime \prime}\right.$ S; $57^{\circ} 54^{\prime}$ 40" W), San José Pass, north James Ross Island, Antarctic Peninsula.

Stratigraphic occurrence. Upper section of the Beta Member (lower-mid Campanian) of the Santa Marta Formation (equivalent to the upper section of Lachman Crags Member after Crame et al., 1991).

Description. Leaf almost bipinnate; pinnae $20 \mathrm{~mm}$ long and $3 \mathrm{~mm}$ wide, each with a straight midvein. Pinnae divided into deeply incised segments of $5 \mathrm{~mm}$ long and $1 \mathrm{~mm}$ wide. Each segment with angular apical sinuses and strong decurrent base giving the appearance of a winged rachis. Each segment forking in its terminal part into a short strip. Segments terminating with an emarginate apex. Segment venation dichotomously branched, each vein terminating at one segment apex. Occasionally two veins converge at terminal dichotomy. One, two, or three branching veins per segment. One basal vein arising in acute angle $\left(\sim 30^{\circ}\right)$.

Comments and comparisons. The arrangement of the pinnae along the rachis, the bifurcating pattern of the segments, and bifid apex of each pinna resemble those of members of the morphogenus Schizaeopsis Berry, 1911 from the Lower Cretaceous Potomac Group of North America and from the Cenomanian of the Czech Republic (Berry, 1911; Kvaček et al., 2006). The fossils are most similar to Schizaea dichotoma
(Linnaeus) Smith, 1793, but differ in having a wider, flabellate pinnae (Kvaček et al., 2006). The absence of cuticular and reproductive characters prevents further comparisons of ANT08 morphotype, and is thus tentatively assigned to Schizaeaceae. Kvaček and Sakala (2011) described fern foliage as cf. Lygodium sp. (Schizaeaceae) for a basal sequence in the Santa Marta Formation, but is has a different leaf shape, with broader and larger pinnae. Further analyses on preserved cuticle and permineralized inner leaf anatomy may help in the identification of ANT08 morphotype among the family.

\author{
incertae sedis \\ Leaf Morphotype ANT07 \\ Figure 3.3-4
}

Studied material. IAA-Pb-24, IAA-Pb-46, IAA-Pb-49.

Geographic occurrence. 'Sitio Feliz' (CF) locality (63 $54^{\prime} 14^{\prime \prime}$ S; $57^{\circ} 54^{\prime}$ 40" W), San José Pass, north James Ross Island, Antarctic Peninsula.

Stratigraphic occurrence. Upper section of the Beta Member (lower-mid Campanian) of the Santa Marta Formation (equivalent to the upper section of Lachman Crags Member after Crame et al., 1991).

Description. Fragment of a long, narrow lamina, $1 \mathrm{~cm}$ wide with a straight, thick midvein ( $1 \mathrm{~mm}$ in width). Secondary veins numerous (14 per centimeter), opposite to subopposite in arrangement. Secondary veins arising in acute angles with decurrent bases, forking once at the vein base. Secondary veins regular in thickness, straight to slightly curved becoming abruptly curved at the margin, joining at acute angle to form a marginal vein. Some secondary veins either fork at the medial blade, but run parallel to other veins. Margin entire, slightly irregular in outline. Blade incurved.

Comments. Cladophlebis macloughlinii Nangalinum and Cantrill, 2015, corresponds to an oblong sterile fern leaf from the Albian of Alexander Island that also shows similar forking veins that arise in straight angles from the midvein and pinnules 2-4 mm in width. ANTO7 is too fragmentary for further comparison with extant species or extinct morphogenera, and the material is here placed incertae sedis among Polypodiopsidae. 
Division GyMnOSPERMOPHYTA auct. pl.

Order CyCADAles Persoon, 1820

Family ZamiaCEAE Horaninow, 1834

Genus et sp. indet.

Leaf Morphotype ANT06

Figure 3.9-11

Studied material. IAA-Pb-23, IAA-Pb-31, IAA-Pb-57.

Geographic occurrence. 'Sitio Feliz' (CF) locality (63 54' 14" S; $57^{\circ} 54^{\prime} 40^{\prime \prime}$ W), San José Pass, north James Ross Island, Antarctic Peninsula.

Stratigraphic occurrence. Upper section of the Beta Member (lower-mid Campanian) of the Santa Marta Formation (equivalent to the upper section of Lachman Crags Member after Crame et al., 1991).

\section{Description}

Leaf. Monopinnate, strong longitudinal ridges running parallel from the pinna base, without forming a midrib. Ten basal veins. Pinnae nearly opposite, with a decurrent base and rounded apical sinus. Pinna base $5 \mathrm{~mm}$ wide. Pinna blade plicate, with 10 to 12 longitudinal acute ridges and rounded sinuses (Fig. 3.9). Rachis straight and stiff, winged, without spines, $1.5 \mathrm{~mm}$ wide.

Epidermis. Thick cuticle. Only the adaxial surface is preserved, which lacks stomata. Glabrous. Epidermal cells elongate, $100 \mu \mathrm{m}$ long and $30 \mu \mathrm{m}$ wide. Flexuous anticlinal cell walls with perforations (Fig. 3.11). No cell differentiation among ridges.

Comments and comparisons. The presence of coriaceous monopinnate leaf, pinnae without a midrib, plicated lamina, thick adaxial cuticle without stomata, with festooned anticlinal walls and perforate surfaces closely resemble leaves of the Zamiaceae (Norstog and Nicholls, 1997) although none present an articulate base. Similar prominent veins giving a plicate appearance similar to that observed in the fossil can be seen on the adaxial surface of the leaves of several Zamia Linnaeus, 1763 species (cf. Taylor et al., 2008).

Centricycas antarcticus Cantrill, 2000 is one of the few confirmed Cretaceous records of Cycadales in Antarctica found in the basal section of Santa Marta Formation near Crame Col (Fig. 1.3). Base and stump anatomy of this species is similar to members of the clade comprising Lepidozamia Regel, 1857, Macrozamia Miquel, 1842, and En- cephalartos Lehmann, 1834. The leaf epidermal characters of the fossils described here also closely match those of the Zamiaceae. This family has fossil record in Antarctica that dates back to the Triassic (Martínez et al., 2012).

Kvaček and Sakala (2011) also describe leaf fragments from the basal section of Santa Marta Formation that they assign to "Zamites vel Dioonites sp.". The poor preservation and absence of cuticle prevents a higher systematic assignment and further comparisons, although they recognized vein anastomoses.

Order PInAles Gorozhankin, 1904

Family AraucariaceAE Henkel and Hochstetter, 1865

Genus Araucaria Jussieu, 1789

Type species. Araucaria araucana (Molina) Koch,1873.

Araucaria fibrosa Césari, Marenssi and Santillana, 2009

Figure 3.5-7

2001 Araucaria 'antarctica' Césari, Marenssi and Santillana, p. 312, figs. 3.a-d, 4-5.

Studied material. IAA-Pb-14, IAA-Pb-15, IAA-Pb-18a, IAAPb-22, IAA-Pb-26, IAA-Pb-27, IAA-Pb-29, IAA-Pb-30, IAAPb-32, IAA-Pb-34, IAA-Pb-35, IAA-Pb-40, IAA-Pb-41, IAA-Pb-47.

Geographic occurrence. 'Sitio Feliz' (CF) locality $\left(63^{\circ} 54^{\prime} 14^{\prime \prime}\right.$ S; $57^{\circ}$ 54' 40" W), San José Pass, northern James Ross Island; and Cape Lamb in the Vega Island.

Stratigraphic occurrence. Upper section of the Beta Member (early-mid Campanian) of the Santa Marta Formation, and K3 level (Marenssi et al., 2001) of Sandwich Bluff Member (mid-late Maastrichtian) from the López de Bertodano Formation.

\section{Description}

Leaves. Large (25 mm wide and $70 \mathrm{~mm}$ long), lanceolate to ovate with acute tips, decurrent base without basal constriction. Abaxialy convex. Leaves thick, $1.2 \mathrm{~mm}$ in thickness, with abundant fibers in the leaf hypodermis (coriaceous in appearance).

Epidermis. Amphistomatic, with persistent longitudinal stomatiferous bands separated by few rows of epidermal cells and thick bundles of fibres (Fig. 3.6-7). Stomata mostly oriented parallel to the long axis of the leaf, but oblique 
and perpendicular stomata are also present at the apex. Anticlinal walls straight.

Comments and comparisons. Large leaves with a broad base correspond to type IV conifer leaves of de Laubenfels (1953) that occur only in the Araucariaceae and Nageia Gaertner, 1788 (Podocarpaceae). Lanceolate leaves with acute apex, abundant presence of fibers and the continuous arrangement of stomata oriented mostly parallel to the long axis are generalized characters of the genus Araucaria (Stockey and Taylor, 1978).

The species Araucaria pararaucana Panti, Césari, Marenssi, and Olivero, 2007 from the Tertiary of Tierra del Fuego match leaf shape and size, although this species has stomata in discontinuous rows, only on one leaf side (probably hypostomatic), and they lack surface fibers, which are abundant in the leaf surface of the new fossils.

The large leaf size and cuticle characters (amphistomatic persistent longitudinal stomatiferous bands, thick fibres bundles) agree with the specific diagnosis for Araucaria fibrosa by Césari et al. (2001, 2009) described from Cape Lamb (Vega Island), in the Sandwich Bluff Member (or K3 level from Marenssi et al., 2001). This new fossil from an older sedimentological unit extends the biostratigraphic range of this species and provides evidence that Araucaria fibrosa occurred at least over an approximately 10 million year period in Antarctica.

\section{Genus Araucarites Presl, 1938}

Type species. Araucarites goeppertti Presl, 1938.

\section{Araucarites sp.}

Figure 3.8

Studied material. IAA-Pb-16, IAA-Pb-17, IAA-Pb-18b, IAAPb-39, IAA-Pb-44, IAA-Pb-45, IAA-Pb-51, IAA-Pb-53.

Geographic occurrence. 'Sitio Feliz' (CF) locality (63 $54^{\prime} 14^{\prime \prime}$ S; $57^{\circ} 54^{\prime}$ 40" W), San José Pass, north James Ross Island, Antarctic Peninsula.

Stratigraphic occurrence. Upper section of the Beta Member (early-mid Campanian) of the Santa Marta Formation (equivalent to the upper section of Lachman Crags Member after Crame et al., 1991).

Description. Detached triangular ovuliferous scale complex.
Bract-scale complex $15 \mathrm{~mm}$ wide and $20 \mathrm{~mm}$ long, with lateral wings and woody in texture. Wings extend, giving a triangular appearance. Seed outline ovoid $5 \mathrm{~mm}$ wide and $15 \mathrm{~mm}$ long, and almost $4 \mathrm{~mm}$ in preserved thickness. Distal tip of the ovuliferous complex wide, although shortly extended. Triangular ligule present. Rectangular epidermal cells in lateral wings in similarly oriented groups (i.e., sister cells; Kendall, 1949).

Comments and comparisons. Araucarites is a fossil genus extensively used for female cones and detached bract-scale complexes (Zijlstra and van Konijnenburg-van Cittert, 2000). As stated by Escapa and Catalano (2013) the absence of seed abscission in such complexes is an unambiguous morphological synapomorphy of the clade that includes Araucarites and extant Araucaria. Further analyses based on cuticle characters and anatomy of permineralized fossils may help in the systematic assignment of these new records among other fossil and/or extant Araucaria species.

Césari et al. (2001) described araucarian ovulate cones from the same fossil site of Araucaria fibrosa in the midupper Maastrichtian of Vega Island (López de Bertodano Formation). The ovuliferous complexes in those cones are rhomboidal, much smaller, i.e., 3.5-4 mm wide and $3 \mathrm{~mm}$ long and bear lateral wings. Lateral wings were recognized in the ovuliferous complex as well.

incertae sedis

Genus Brachyphyllum (Brongniart) Harris, 1969

Type species. Brachyphyllum mamillare Brongniart, 1828.

\section{Brachyphyllum sp.1}

Figure 3.12

Studied material. IAA-Pb-21, IAA-Pb-50.

Geographic occurrence. 'Sitio Feliz' (CF) locality (63 54' 14" S; $57^{\circ} 54^{\prime} 40^{\prime \prime}$ W), San José Pass, north James Ross Island, Antarctic Peninsula.

Stratigraphic occurrence. Upper section of the Beta Member (lower-mid Campanian) of the Santa Marta Formation (equivalent to the upper section of Lachman Crags Member after Crame et al., 1991).

Description. Branches bearing helically arranged leaves. Leaves spirally arranged, scale-like, densely imbricate; free 
portion of leaf (i.e., no stem attached) $2 \mathrm{~mm}$ long, $1.5 \mathrm{~mm}$ wide, broader at the base; margin erose. Apex convex. Cushions more or less rhomboidal, decurrent base attachments $2.4 \mathrm{~mm}$ long.

Cuticle. Hypostomatic leaf, stomata randomly oriented (indistinct rows) along both sides of the keel.

Comments and comparisons. The incertae sedis genus Brachyphyllum has characteristics shared by several different conifer groups. The original description by Brongniart (1828) was emended by Harris (1969) to include leaves that are spirally arranged and have a free leaf portion shorter than the width of the cushion; and with a short tip. Although fragmentary and scarce, Brachyphyllum in this new locality suggests a constant presence in Cretaceous floras of the Antarctic Peninsula (Cantrill and Poole, 2012). Kvaček and Sakala (2011) described the presence of Brachyphyllum in the underlying Hidden Lake Formation (Coniacian, James Ross Island).

\section{Genus Pagiophyllum Heer, 1881}

Type species. Pagiophyllum circinicum Heer, 1881.

\section{Pagiophyllum sp. 1}

Figure 3.13

Studied material. IAA-Pb-25.

Geographic occurrence. 'Sitio Feliz' (CF) locality (63 54' 14" S; $57^{\circ} 54^{\prime}$ 40" W), San José Pass, north James Ross Island, Antarctic Peninsula.

Stratigraphic occurrence. Upper section of the Beta Member (lower-mid Campanian) of the Santa Marta Formation (equivalent to the upper section of Lachman Crags Member after Crame et al., 1991).

Description. Branches with helically arranged straight leaves. Free portion of leaf (i.e., no stem attached) 3 mm long. Basal portion narrow (0.5 mm wide) and $2 \mathrm{~mm}$ long. Leaf apex acute. Leaves have a single, medial vein.

Comments and comparisons. Pagiophyllum (Heer, 1881) shares characteristics belonging to several types of conifers all of which exhibit spirally arranged leaves with broad decurrent bases, and with the free part larger than the decurrent part. Pagiophyllum sp. 1 from this locality differ from Pagiophyllum sp. 2 in having straight leaves, larger free leaf por- tion, and a more laxer disposition of leaves in the spiral (symmetric section). Kvaček and Sakala (2011) also described two Pagiophyllum species from the Hidden Lake Formation.

\section{Pagiophyllum sp. 2}

Figure 3.14

Studied material. IAA-Pb-37.

Geographic occurrence. 'Sitio Feliz'(CF) locality (63 $54^{\prime} 14^{\prime \prime}$ S; $57^{\circ} 54^{\prime} 40^{\prime \prime}$ W), San José Pass, north James Ross Island, Antarctic Peninsula.

Stratigraphic occurrence. Upper section of the Beta Member (lower-mid Campanian) of the Santa Marta Formation (equivalent to the upper section of Lachman Crags Member after Crame et al., 1991).

Description. Branches with helically arranged leaves. Leaves curved with free portion of leaf (i.e., no stem attached) 2.4 $\mathrm{mm}$ long, $1 \mathrm{~mm}$ wide, and with a convex apex. Basal portion narrow (0.7 mm wide) and $1.5 \mathrm{~mm}$ long. Triangular to rhomboidal in section. One vein running close to the abaxial leaf surface.

Comments and comparisons. Pagiophyllum sp. 2 differs from Pagiophyllum sp. 1 in that Pagiophyllum sp. 2 leaves are more curved with a shorter free portion, and that leaves are more densely disposed, with the mid vein running on the abaxial leaf surface forming a triangular to rhomboidal leaf section. Kvaček and Sakala (2011) also described a morphologically distinct Pagiophyllum species from the Hidden Lake Formation, which also are triangular in section.

\section{Division ANGIOSPERMOPHYTA}

Order Oxalidales Berchtold, and Presl, 1820

Family ?CUNONIACEAE Brown, 1814

Leaf Morphotype ANT01

Figures $4.5-7,5.4$

Studied material. IAA-Pb-42, IAA-Pb-54, IAA-Pb-55, IAAPb-56, IAA-Pb-61.

Geographic occurrence. 'Sitio Feliz' (CF) locality $\left(63^{\circ} 54^{\prime} 14^{\prime \prime}\right.$ S; $57^{\circ} 54^{\prime}$ 40" W), San José Pass, north James Ross Island, Antarctic Peninsula.

Stratigraphic occurrence. Upper section of the Beta Member 
(lower-mid Campanian) of the Santa Marta Formation (equivalent to the upper section of Lachman Crags Member after Crame et al., 1991).

Description. Microphyllous narrow ovate leaf, weakly asymmetric at base, measuring $3 \mathrm{~cm}$ long by $2 \mathrm{~cm}$ wide, appearance chartaceous in texture. Petiole insertion marginal. Base angle acute. Apex angle very acute and cuneate (straight). Margin dentate with small convex teeth $(0.3 \mathrm{~mm})$, not present at leaf base; three teeth per centimeter. Sinus rounded. Tooth apex non-glandular. Tooth venation supplied by a separate vein arising from a secondary arc; accessory tooth venation looped. Primary venation pinnate, primary vein thick (strong), with a straight to slightly curved course.
Secondary venation semicraspedodromous with seven pairs of secondaries, irregularly curved and forking near the margin, subopposite on the midvein, base decurrent, secondary angle increasing basally, spacing decreases towards the base. Along the margin, secondary veins join in loops at acute angles. Basal agrophic veins absent. Three basal veins (a medial vein and two lateral acute secondaries). Intersecondary veins weak, simple, thinner at the margin, irregular in course. Tertiary venation pattern percurrent mixed opposite-alternate, course straight or convex, with wide angles of divergence, acute to primary, tertiary angles increasing apically. Fourth order veins regular polygonal reticulate. Fifth order veins regular polygonal reticulate.
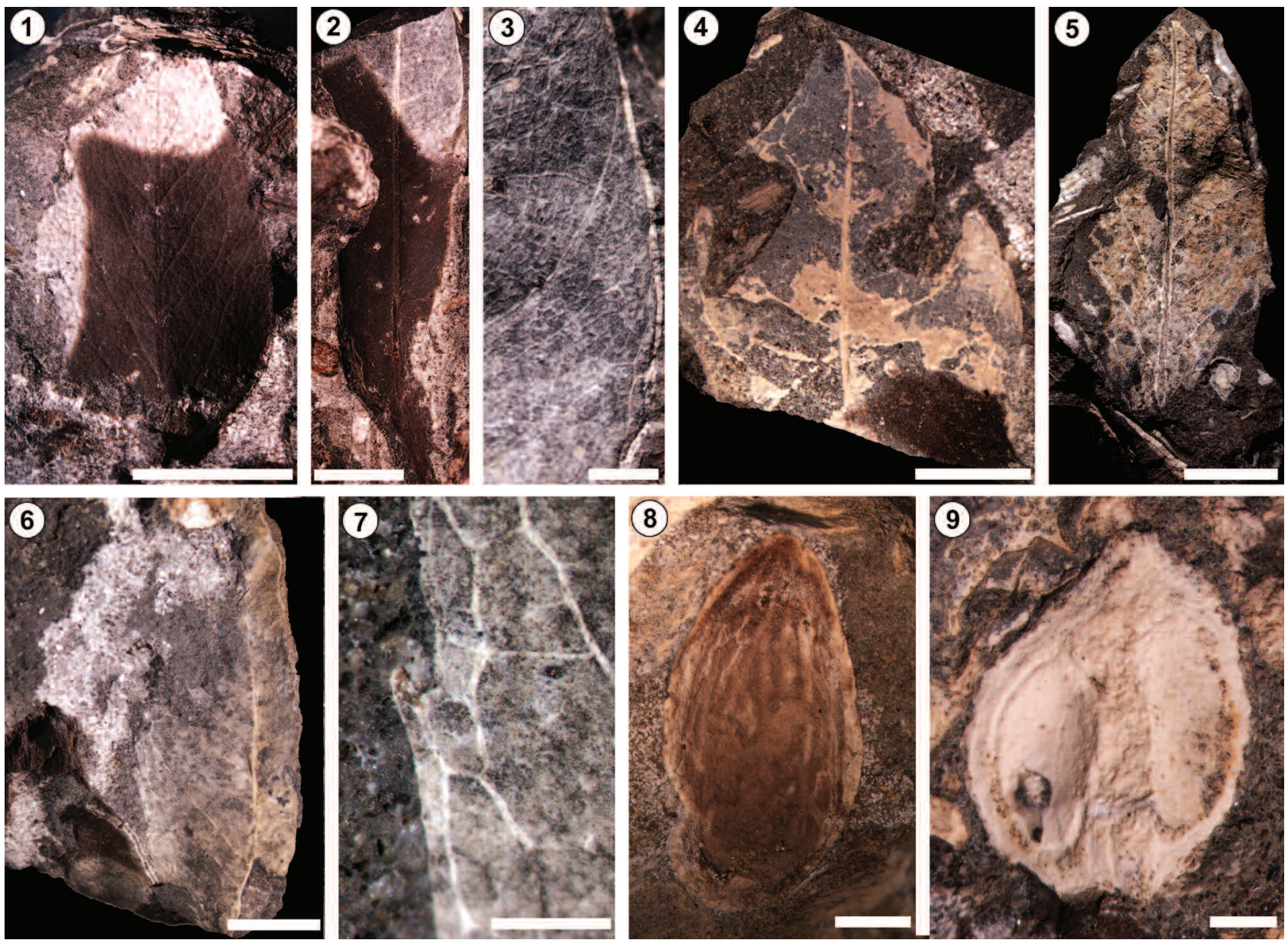

Figure 4. Angiosperms from Santa Marta Formation (early-mid Campanian), James Ross Island. 1, ANT03 morphotype (IAA-Pb-59). 2, ANT04 morphotype (IAA-Pb-58). 3, leaf venation of same specimen as in Figure 4.2. 4, Lauraceae ANTO2 morphotype (IAA-Pb-52). 5-7, ?Cunoniaceae ANT01 morphotype; 5, IAA-Pb-54; 6, IAA-Pb-42; 7, tooth venation of same specimen as in Figure 4.6. 8, Carpolithus sp. 1 woody endocarp with longitudinal ridges (IAA-Pb-43). 9, Carpolithus sp. 2 woody endocarp showing two of its locules (IAA-Pb-19). Scale bars= 10 mm (1, 2, 4, 5); $2 \mathrm{~mm}(3,8) ; 5 \mathrm{~mm}(6) ; 1 \mathrm{~mm}(7,9)$. 
Areolation very well developed, size medium (1-0.3 mm), shape pentagonal. Marginate ultimate venation looped. Freely ending ultimate veins (FEVs) 2 or more ramified.

Comments and comparisons. The presence of teeth with nonglandular apices coupled with the tooth venation suggests ANT01 teeth bears cunonioid type teeth (cf. Hickey and Wolfe, 1975). Cunonioid teeth are observed in members of the Cunoniaceae but also in several other unrelated plant families (e.g., Sapindales). ANT01 morphotype presents a combination of characters (i.e., semicraspedodromous secondary venation, secondary angle increasing basally, spacing decreasing toward base, and very well developed areolation) that has not previously been observed in Antarctic floras.

Order LauRALES Jussieu ex Berchtold and Presl, 1820

Family LAURACEAE Jussieu, 1789

incertae sedis

Leaf Morphotype ANT02

Figures 4.4, 5.1, 5.5

Studied material. IAA-Pb-33, IAA-Pb-52.

Geographic occurrence. 'Sitio Feliz' (CF) locality (63 54' 14" S; $57^{\circ} 54^{\prime} 40^{\prime \prime}$ W), San José Pass, north James Ross Island, Antarctic Peninsula.

Stratigraphic occurrence. Upper section of the Beta Member (lower-mid Campanian) of the Santa Marta Formation (equivalent to the upper section of Lachman Crags Member after Crame et al., 1991).

Description. Microphyllous ovate leaf, symmetrical, length 4 $\mathrm{cm}$, width $3 \mathrm{~cm}$ with coriaceous texture. Petiole marginal. Base angle obtuse. Apex angle acute, apex shape acuminate, extended into a drip tip. Margin entire. Primary venation pinnate. Strong and straight medial vein. Secondary venation brochidodromous. Secondaries subopposite, joining to supradjacent at right angles. Secondary veins moderate in thickness, curved; base decurrent. Four pairs of secondary veins, spacing and angles of insertion both increasing towards base. Agrophic veins absent. Intersecondary veins simple, two to three per intercostal area. One basal vein. Tertiary venation polygonal reticulate, perpendicular to primary and secondaries. Tertiary veins thickness moderate, course straight. Inconsistent tertiary angles.
Fourth order veins thickness moderate, regular polygonal reticulate. Areolation moderately developed, areoles 4-5 sided. FEVs branched, arise perpendicularly. Looped ultimate marginate venation. Presence of small resin dots on the leaf surface.

Comments and comparisons. Morphotype ANT02 resembles some of the line drawings illustrated in Hayes et al. (2006) of leaves with brochidodromous venation and drip tips. Further descriptions are absent from Hayes et al. (2006) that prevent closer comparison. Small dots on the leaf surface were observed on ANT02 under fluorescence microscopy (Fig. 5.1) that are recognized as resin bodies (Platt and Thomson, 1992). Resin dots and several characters such as the brochidodromous venation and well developed drip tip suggest that this leaf form might belong to the Lauraceae.

Family indet.

Leaf Morphotype ANT03

Figures 4.1, 5.3

Studied material. IAA-Pb-59.

Geographic occurrence. 'Sitio Feliz' (CF) locality (63 54' 14" S; $57^{\circ} 54^{\prime} 40^{\prime \prime}$ W), San José Pass, north James Ross Island, Antarctic Peninsula.

Stratigraphic occurrence. Upper section of the Beta Member (lower-mid Campanian) of the Santa Marta Formation (equivalent to the upper section of Lachman Crags Member after Crame et al., 1991).

Description. Microphyllous ovate leaf, symmetrical, length $2.3 \mathrm{~cm}$ and width $1.5 \mathrm{~cm}$. Petiole insertion marginal. Base angle acute, base shape rounded. Apex angle acute, apex shape cuneate. Margin entire. Primary venation pinnate, midvein thickness moderate, course straight. Secondary venation festooned brochidodromous, secondaries with irregular course, forking and joining at different angles. Nine pairs of secondary veins, thickness moderate, arising with homogeneous angles of $45^{\circ}$ with strongly decurrent bases, course irregularly curved. Secondary spacing increasing toward base, secondary angles with irregular pattern. Intersecondary veins thin, simple, one per intercostal area, straight in course, irregularly ending. One basal vein. Tertiary venation alternate percurrent, irregularly reticulate at the leaf base, course straight, tertiary angles not uniform. Fourth order veins thin, polygonal reticulate pattern, course 
irregular. Fifth order veins dichotomizing. Areolation well developed, size irregular (larger at leaf base), shape rhomboidal. FEVs 2 or more ramified. Marginal ultimate venation looped with thin veins. Foliar rank $2 r$.

Comments and comparisons. ANT03 morphotype resembles some of the line drawings illustrated in Hayes et al. (2006), were leaves shows entire margin and festooned brochidodromous secondary venation. ANT03 morphotype exhibits a combination of characters that has not previously been observed in other Gondwanan floras, such as festooned brochidodromous secondary venation, low venation organization, secondary angles homogeneous, secondary spacing increasing toward base, areole size irregular with rhomboidal shape.

\section{Leaf Morphotype ANT04}

Figures 4.2-3, 5.2

Studied material. IAA-Pb-36, IAA-Pb-58.

Geographic occurrence. 'Sitio Feliz' (CF) locality (63 54' 14" S; $57^{\circ} 54^{\prime} 40^{\prime \prime}$ W), San José Pass, north James Ross Island, Antarctic Peninsula.
Stratigraphic occurrence. Upper section of the Beta Member (lower-mid Campanian) of the Santa Marta Formation (equivalent to the upper section of Lachman Crags Member after Crame et al., 1991).

Description. Microphyllous narrow elliptic leaf, symmetrical, length $6 \mathrm{~cm}$, width $1.5 \mathrm{~cm}$. Petiole insertion marginal. Base angle acute, base shape cuneate. Apex angle acute. Margin entire. Primary venation pinnate, midvein thickness strong, course straight. Secondary venation eucamptodromous becoming brochidodromous distally. Nine pairs of secondary veins, thickness thin, arising with straight angles, course curved, being parallel to the margin. Secondary spacing uniform. A thin intramarginal vein formed by secondary loops, running far from the margin. Intersecondary veins weak, one per intercostal area, with curved course. One basal vein. Tertiary venation opposite percurrent, course convex, perpendicular to primary, tertiary angles increasing exmedially. Fourth order veins thickness strong, regular polygonal reticulate pattern, course straight. Fifth order veins strong regular polygonal reticulate pattern, course straight. Areolation moderately developed. FEVs 2 or more ramified. Marginal ultimate venation looped.
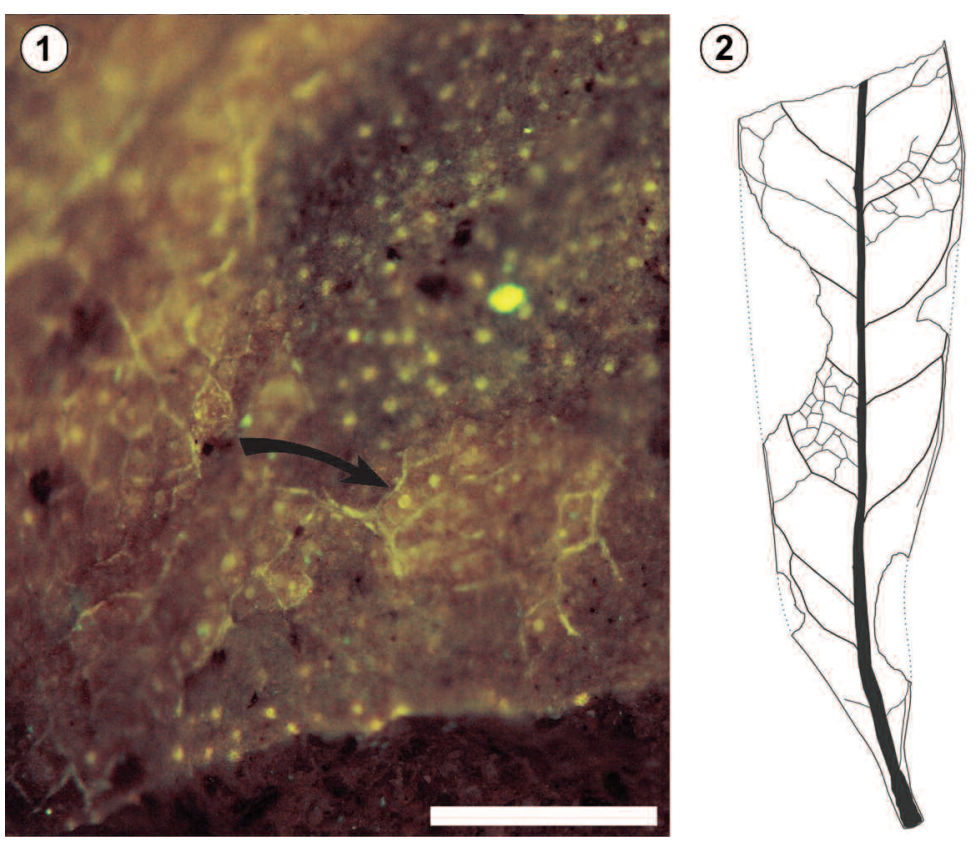

(3)

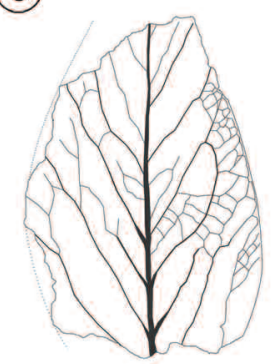

(5)

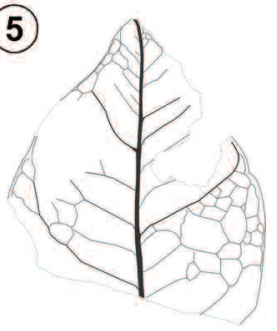

(4)

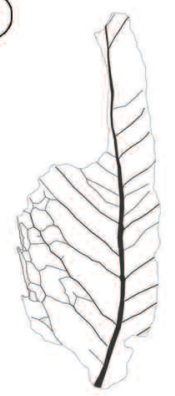

(6)

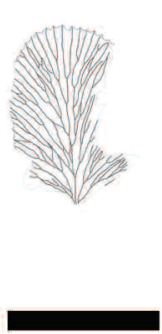

Figure 5. Leaves from Santa Marta Formation (early-mid Campanian), James Ross Island. 1, Lauraceae ANT02 morphotype (IAA-Pb-33) showing preserved resin dots (arrow) under fluorescence microscopy. 2, ANT04 morphotype (IAA-Pb-58). 3, ANT03 morphotype (IAA-Pb-59). 4, ?Cunoniaceae ANT01 morphotype (IAA-Pb-42). 5, Lauraceae ANT02 morphotype (IAA-Pb-52). 6, Pteridaceae ANT05 morphotype (IAA-Pb20). Line drawings at same black scale bar $=1 \mathrm{~mm}(1) ; 5 \mathrm{~mm}(2-6)$. 
Comments and comparisons. ANT04 morphotype does not resemble any of the line drawings published in Hayes et al. (2006). ANTO4 presents a combination of characters that has not previously been observed in Antarctic floras, such as narrow elliptic shape, secondary venation eucamptodromous, with thin secondary veins, and moderately developed areolation. Narrow elliptic leaves are known for the Upper Cretaceous in southern South America (Hünicken, 1995; Iglesias et al., 2007; Archangelsky et al., 2009).

Morphogenus Carpolithus Linnaeus emend. Seward, 1917

\section{Carpolithus sp. 1}

Figure 4.8

Studied material. IAA-Pb-43.

Geographic occurrence. 'Sitio Feliz' (CF) locality (63 54' 14" S; $57^{\circ} 54^{\prime}$ 40" W), San José Pass, north James Ross Island, Antarctic Peninsula.

Stratigraphic occurrence. Upper section of the Beta Member (lower-mid Campanian) of the Santa Marta Formation (equivalent to the upper section of Lachman Crags Member after Crame et al., 1991).

Description. Radial symmetrical ovate fruit, $9.5 \mathrm{~mm}$ long, 5 $\mathrm{mm}$ wide. Unilocular, bicarpelate-valvate. Chalazal region rounded, apical region acute acuminate. Endocarp surface with discontinuous longitudinally flexuous ridges, running from chalazal to micropylar region with similar thickness, giving a brain-like appearance. Ridges $0.4 \mathrm{~mm}$ wide, in strong relief in association with longitudinal fibres bundles. Comments and comparisons. Carpolithus sp. 1 represents the external preservation of a reproductive structure, possibly the woody endocarp of a nut-like drupe fruit type. It is assigned to the incertae sedis morphogenus Carpolithus Linnaeus emend. Seward (Seward, 1917), with which shows greatest morphological similarity according to the Cretaceous bibliography for seed and fruits (e.g., Tiffney, 1984). It should be noted that many species assigned to Carpolithus are so different that this morphogenus clearly represents different genera and even higher order taxa (Tiffney,1984; Manchester, 1994).

\section{Carpolithus sp. 2}

Figure 4.9
Studied material. IAA-Pb-19.

Geographic occurrence. 'Sitio Feliz' (CF) locality (63 54' 14" S; $57^{\circ} 54^{\prime}$ 40" W), San José Pass, north James Ross Island, Antarctic Peninsula.

Stratigraphic occurrence. Upper section of the Beta Member (lower-mid Campanian) of the Santa Marta Formation (equivalent to the upper section of Lachman Crags Member after Crame et al., 1991).

Description. Endocarp subglobose, asymmetrical at the micropylar region, $6 \mathrm{~mm}$ long, $4.7 \mathrm{~mm}$ wide. Plurilocular leaving a central columella $1 \mathrm{~mm}$ wide. Endocarp wall with spongy structure. Base shape rounded, micropylar shape acuminate. Funicular attachment $1.4 \mathrm{~mm}$ wide. Seeds kidney-shaped, $3.6 \mathrm{~mm}$ long, $1.6 \mathrm{~mm}$ wide, with a smooth surface.

Comments and comparisons. Carpolithus sp. 2 represents the internal preservation of a reproductive structure, which represents the woody endocarp and cast of locules of a superior ovary fruit type. Following Cretaceous bibliography for seed and fruits it is assigned to the incertae sedis morphogenus Carpolithus Linnaeus emend. Seward. Carpolithus sp. 2 is clearly distinct from Carpolithus sp. 1 in having a shorter and broader asymmetric shape, more than one locule and a spongy endocarp. Carpolithus sp. 1 clearly differs from Carpolithus sp. 2 in being larger, multi-seeded, more narrow elliptical shape and endocarp fiber orientation

\section{DISCUSSION}

This new macroflora from the Santa Marta Formation provides evidence of a diverse Upper Cretaceous macroflora containing three different ferns (including Pteridaceae and ?Schizaeaceae), a cycad (Zamiaceae), conifers (Araucariaceae, Podocarpaceae), and angiosperms (Lauraceae, ?Cunoniaceae) in the eastern Antarctic Peninsula (James Ross Basin).

The Zamiaceae recorded here is the youngest leaf fossil record of cycads in Antarctica. A permineralized stem and probable leaf fragments of this family have been recorded from older strata of the same litostratigrahic unit (Cantrill, 2000; Kvaček and Sakala, 2011).

The Araucariaceae record is common in Antarctic paleofloras dating from the Mesozoic to Paleogene. The recovery of the same species found López de Bertodano Formation (Maastrichtian) on Vega Island has expanded the 
age range for this taxon. Further studies on the association of the ovuliferous complex in the new material from Santa Marta Formation (Fig. 3) and seed cones described from the Snow Hill Island Formation (Césari et al., 2001) could help in a better placement of this species among the different sections of Araucaria.

Three different conifer leaf forms are described here from the lower Campanian of James Ross Island. The two coniferous genera (Brachyphyllum and Pagiophyllum) could be associated with conifer woods previously reported within the sedimentological sequence, including Araucariopitys (Araucariaceae) and Podocarpoxylon (Podocarpaceae; Francis, 1986; Poole and Fancis, 1999, 2000; Poole et al., 2000a, b; Poole and Gottwald, 2001; Cantrill and Poole, 2005). Kvaček and Sakala (2011) recorded these same conifer genera from the Hidden Lake Formation and the basal sequence of Santa Marta Formation on James Ross Island, although they did not provide a complete description.

Fern fronds found in this flora record two different leaf forms: Pteridaceae and ?Schizaeaceae. Both families were known by their spore record, although more common during earlier Cretaceous times (Dettmann and Thomson, 1987; Baldoni, 1992).

Four new leaf morphotypes and two fruits of angiosperms were described. The identification of Lauraceae can be certified by the leaf architecture and presence of resin dots in ANTO2 morphotype. Nonetheless the systematic assignation of ANT01 morphotype to Cunoniaceae remains dubious until more decisive characters are observed.

A diversity of angiosperm leaves has been recorded from the Coniacian through to Campanian of the James Ross Basin but never formally described (Hayes, 1999; Hayes et al., 2006; Kvaček and Sakala, 2011). This fact makes comparisons difficult and I have thus relied on the line drawings in Hayes et al. (2006) to compare angiosperm leaves. As noted above, ANT04 morphotype resembles some line drawings illustrated in Hayes et al. (2006).

Systematic conclusions here presented, in part, are supported by the Cretaceous fossil wood record which has been described in detail in several units for the James Ross Basin. The wood species Laurelites jamesrossii from Santa Marta Formation was assigned to Atherospermataceae (Order Laurales) by Poole and Francis (1999). Although there are not enough characters in ANTO1 to confirm their systematic emplacement in Cunoniaceae, the record of Weinmannioxylon nordenskjoeldii (Poole et al., 2000a) in the Hidden Lake Formation and basal member of Santa Marta Formation confirms the earlier presence of this family for the basin (Cantrill and Poole, 2012).

Particularly, the presence of a diverse flora containing ferns, podocarps and mostly entire margin angiosperm leaves may indicate near constant humid conditions (absence of marked dry season) although they may be exposed to an extremely seasonal light regime (Cantrill and Poole, 2012). The Cycadales are the most thermophilic group found within the whole Cretaceous Antarctic fossil record, and the confirmed fossil record in Santa Marta Formation may also indicate a frost free environment (e.g., Norstog and Nicholls, 1997) for the early Campanian in continental areas of the Antarctic Peninsula, as was suggested by other proxies (Birkenmajer and Zastawniak, 1989; Hubber et al., 1995; Francis and Poole, 2002; Miller et al., 2005; Hayes et al., 2006).

The earliest certain records of angiosperm in Antarctica are those of pollen from the early to mid Albian of James Ross Island (Dettman and Thomson, 1987; Riding and Crame, 2002). After the earliest macrofossil evidence from late Albian in the Antarctic Peninsula (Cantrill and Nichols, 1996), angiosperm shows an increase in abundance and diversity during Albian-Cenomanian times (Cantrill and Poole, 2002), reaching a pollen peak record in the Coniacian (Dettman and Thompson, 1987). Angiosperm dominated macrofloras were recorded since the Coniacian in the Antarctic Peninsula (Cantrill and Poole, 2012). Hayes et al. (2006) have recognized 41 angiosperm leaves, but they included several fossiliferous strata from both Hidden Lake (Coniacian) and lower levels (earlier Campanian) of Santa Marta formations. Kvaček and Sakala (2011) recognized 21 angiosperm forms in the Hidden Lake Formation and 11 in the lower strata of Santa Marta Formation.

No studies have found evidence of the Nothofagaceae for these basal sequences, although in Eastern Antarctica seems to be present since the early Campanian (Askin, 1992) and by the late Campanian (Gamma Member) the four modern pollen types are known for the James Ross Basin (Dettman and Thomson, 1987; Swenson et al., 2000). The later seems to be reinforced by the fact that until now, lower Upper Cretaceous angiosperm leaves from the 
western side of the Antarctic Peninsula (Rees and Smellie, 1989; Cantrill and Nicholls, 1996) do not share similarities in leaf architecture with those from the James Ross Basin. Probable floristic change was recorded in Antarctic Peninsula as was suggested also by palynology and wood taxa (Dettmann and Thomson, 1987; Askin, 1992; Barreda et al., 1999; Poole and Cantrill, 2006). Thus, the present study from the Beta Member of Santa Marta Formation represents an improvement in the resolution of early-mid Campanian floras knowledge for the Antarctic Peninsula macrofloras.

\section{ACKNOWLEDGMENTS}

I want to thank J. O'Gorman, R. Coria, M. Fernández, M. Reguero, E. Olivero, M.E. Raffi, F. Milanese, C. Acosta Hospitaleche, and J. Gelfo for valuable help at field works. Also thanks to UNLP technicians J.J. Molly, M. de los Reyes, and IAA technicians J. Dellachá, J. Lusky, G. Mamaní, and M.A. Ríos for project collaboration. To M. Salgado (UNCOMA) for fossil preparation and S. Little for their comments. I also thank the reviewers (I. Pool, T. Dutra, and A. Otero) and their comments that considerably improved the manuscript. Financial support has been provided by the Argentinean National Agency for Science and Technology Promotion (PICTO-2010-0093; and PICT-2013-0388) and by Argentinean Antarctic Institute (DNAIAA).

\section{REFERENCES}

Archangelsky, S., Barreda, V., Passalia, M.G., Gandolfo, M., Prámparo, M., Romero, E., Cúneo, R., Zamuner, A., Iglesias, A., Llorens, M., Puebla, G.G., Quattrocchio, M., and Volkheimer, W. 2009. Early angiosperm diversification: evidence from southern South America. Cretaceous Research 30: 1073-1082.

Ash, A.W., Ellis, B., Hickey, L.J., Johnson, K.R., Wilf, P., and Wing, S.L. 1999. Manual of Leaf Architecture: Morphological Description and Categorization of Dicotyledonous and Net-Veined Monocotyledonous Angiosperms. Leaf Architecture Working Group (Eds.), Smithsonian Institution, Washington D.C., 67 p.

Askin, R. 1988. Campanian to Paleocene palynological succession of Seymour and adjacent islands, northeastern Antarctic Peninsula. Geological Society of America Memoir 169: 131-153.

Askin, R. 1992. Late Cretaceous-early Tertiary Antarctic outcrop evidence for past vegetation and climates. In: J.P. Kennett, and D.A. Warnke (Eds.), The Antarctic Paleoenvironment: A perspective on global change. Part. 1. Antarctic Research Series 56, American Geophysical Union, Washington, p. 61-73.

Baldoni, A. 1992. Palinología de la Formación Santa Marta, Cretácico Superior de la Isla James Ross, Antartida. In: C.A. Rinaldi (Ed.), Geología de la Isla James Ross. Instituto Antártico Argentino, Buenos Aires, p. 359-374.

Barreda, V., Palamarzuk, S., and Medina, F. 1999. Palinología de la Formación Hidden Lake (Coniaciano-Santoniano), Isla Jamess Ross, Antártida. Revista Española de Micropaleontología 31: 53-72.

Berchtold, F., and Presl, J.S. 1820. Prirozenosti Rostlin aneb rostlinár. Joseph Krause, Prague, $221 \mathrm{p}$.

Berry, E.W. 1911. A Lower Cretaceous species of Schizaceae from eastern North America. Annals of Botany 25: 193-199.

Birkenmajer, K., and Zastawniak, E. 1989. Late Cretaceous-Early
Neogene vegetation history of the Antarctic Peninsula sector, Gondwana break-up and Tertiary glaciations. Bulletin of the Polish Academy of Sciences, Earth Sciences 37: 63-88.

Brown, R.1814. General Remarks, Geographical and Systematical, on the Botany of Terra Australis. In: M. Flinders (Ed.), A voyage to Terra Australis undertaken for the purpose of completing the discovery of that vast country, and prosecuted in the years 1801, 1802, and 1803, vol. 2. W. Bulmer and Co., London, p. 533-613.

Brongniart, $A$. 1828. Prodrôme d'une histoire des végétaux fossiles. Dictionnaire des Sciences Naturelles 57: 16-212.

Cantrill, D.J. 2000. A petrified cycad trunk from the Late Cretaceous of the Larsen Basin, Antarctica. Alcheringa 24: 307-318.

Cantrill, D.J., and Nichols, G.J. 1996. Taxonomy and palaeoecology of Early Cretaceous (Late Albian) angiosperm leaves from Alexander Island, Antarctica. Review of Palaeobotany and Palynology 92: 1-28.

Cantrill, D.J., and Poole, I. 2002. Cretaceous patterns of floristic change in the Antarctic Peninsula. In: J.A. Crame, and A.W. Owen (Eds.), Paleobiogeography and biodiversity change: the Ordovician and Mesozoic-Cenozoic radiations. Geological Society of London Special Publication 194, London, p. 141-152.

Cantrill, D.J., and Poole, I. 2005. Taxonomic turnover and abundance in Cretaceous to Tertiary wood floras of Antarctica: implications for changes in forest ecology. Palaeogeography, Palaeoclimatology, Palaeoecology 215: 205-219.

Cantrill, D.J., and Poole, I. 2012. The vegetation of Antarctica through geological time. Cambridge University Press, Cambridge, 480 p.

Carvalho, M.A., Cabral Ramos, R.R., Crud, M.B., Witovisk, L., Kellner, A.W.A., Silva, H.P., Grillo, O.N., Riff, D., and Romano, P.S.R. 2013. Palynofacies as indicators of paleoenvironmental changes in a Cretaceous succession from the Larsen Basin, James Ross Island, Antarctica. Sedimentary Geology 295: 53-66.

Césari, S.N., Marenssi, S.A., and Santillana, S.N. 2001. Conifers from the Upper Cretaceous of Cape Lamb, Vega Island, Antarctica. Cretaceous Research 22: 309-319.

Césari, S.N., Marenssi, S.A., and Santillana, S.N. 2009. Araucaria fibrosa, a new name to replace the illegitimate name Araucaria antarctica Césari, Marenssi and Santillana, 2001. Cretaceous Research 30: 1169.

Christenhusz, M.J.M., Reveal, J.L., Farjon, A., Gardner, M.F., Mill, R.R., and Chase, M.W. 2011. A new classification and linear sequence of extant gymnosperms. Phytotaxa 19: 55-70.

Crame, J.A., Pirrie, D., and Riding, J.B. 2006. Mid-Cretaceous stratigraphy of the James Ross Basin, Antarctica. In: J.E. Francis, D. Pirrie, and J.A. Crame (Eds.), Cretaceous-Tertiary HighLatitude Palaeoenvironments, James Ross Basin. Antarctica. Geological Society Special Publications 258, London, p. 7-19.

Crame, J.A., Francis, J.E., Cantrill, D.J., and Pirrie, D. 2004. Maastrichtian stratigraphy of Antarctica. Cretaceous Research 25: 411-423.

Crame, J.A., Pirrie, D., Riding, J.B., and Thomson, M.R.A. 1991. Campanian-Maastrichtian (Cretaceous) stratigraphy of the James Ross Island area, Antarctica. Journal of the Geological Society 148: 1125-1140.

Cronquist, A., Takhtajan, A.L., and Zimmerman, W. 1966. On the higher taxa of embryobionta. Taxon 15: 129-134.

Del Valle, R.A., Elliot, D.H., and Macdonald, D.I.M. 1992. Sedimentary basins on the east flank of the Antarctic Peninsula: proposed nomenclature. Antarctic Science 4: 477-478.

Dettmann, M.E., and Thomson, M.R.A. 1987. Cretaceous palynomorphs from the James Ross Island area, Antarctica-a pilot study. British Antarctic Survey Bulletin 77: 13-59.

Douglas, J.G., and Williams, G.E. 1982. Southern Polar Forests: The 
Early Cretaceous floras of Victoria and their palaeoclimatic significance. Palaeogeography, Palaeoclimatology, Palaeoecology 39: 171-185.

Dutra, T.L., and Batten, D. 2000. The Upper Cretaceous flora from King George Island, an update of information and the paleobiogeographic value. Cretaceous Research 21: 181-209.

Elliot, D.H. 1988. Tectonic setting and evolution of the James Ross Basin, northern Antarctic Peninsula. In: R.M. Feldmann, and M.O. Woodburne (Eds.), Geology and paleontology of Seymour Island, Antarctic Peninsula. Geological Society of America Memoir 169, Tucson, p. 541-555.

Ellis, B., Douglas, C.D., Hickey, L.J., Johnson, K.R., Mitchell, J.D., Wilf, P., and Wing, S.L. 2009. Manual of leaf architecture. Cornell University Press, New York, 190 p.

Escapa, I.H., and Catalano, S.A. 2013. Phylogenetic analysis of Araucariaceae: Integrating molecules, morphology, and fossils. International Journal of Plant Sciences 174: 1153-1170.

Falcon-Lang, H.J., and Cantrill, D.J. 2001. Leaf phenology of some mid-Cretaceous polar forests, Alexander Island, Antarctica. Geological Magazine 138: 39-52.

Florisbal, L.S., Diemer, K., Diemer-Kochhann, C.G., Baecker-Fauth, S., and Fauth, G. 2013. Benthic foraminifera, ostracods and radiolarians from the Lachman Crags Member (Santa Marta Formation), Upper Santonian-Lower Campanian (Upper Cretaceous) of James Ross Island, Antarctica. Revista Brasileira de Paleontologia 16: 181-196.

Francis, J.E. 1986. Growth rings in Cretaceous and Tertiary wood from Antarctica and their palaeoclimatic implications. Palaeontology 29: 665-684.

Francis, J.E., and Poole, I. 2002. Cretaceous and early Tertiary climates of Antarctica: evidence from fossil wood. Palaeogeography, Palaeoclimatology, Palaeoecology 182: 47-64.

Francis, J.E., Ashworth, A., Cantrill, D.J., Crame, J.A., Howe, J., Stephens, R., Tosolini, A.M., and Thorn, V. 2008. 100 million years of Antarctic climate evolution: evidence from fossil plants. In: A.K. Cooper, P. Barrett, H. Stagg, B. Storey, E. Stump, and W. Wise (Eds.), Antarctica: a keystone in a changing world. Proceedings of the $10^{\text {th }}$ International Symposium on Antarctic Earth Sciences. National Academy Press, Washington, p. 19-27.

Gaertner, J. 1788. De Fructibus et Seminibus Plantarum vol. 1. Academiae Carolinae, Stuttgart, $191 \mathrm{p}$.

Gorozhankin, I.N. 1904. Lektsii po morfologii i sistematike archegonialnykh rastenij. A.I. Mamontov, Moscow, 79 p.

Harris, T.M. 1969. Naming a fossil conifer. In: H. San- tarau (Ed.), J. Sen Memorial Volume. Botanical Society of Bengal, Calcutta, p. 243-252.

Hayes, P.A. 1999. [Cretaceous angiosperm leaf floras from Antarctica. PhD. Thesis, University of Leeds, United Kindom, 310 p. Unpublished.].

Hayes, P.A., Francis, J.E., Cantrill, D.J., and Crame, J.A. 2006. Paleoclimate analysis of Late Cretaceous angiosperm leaf floras. Jame Ross Island, Antarctica. In: J.E. Francis, D. Pirrie, and J.A. Crame (Eds.), Cretaceous-Tertiary High Latitude Paleoenvironments, James Ross Basin, Antarctica. Geological Society of London, Special Publication 258, p. 49-62.

Heer, O. 1881. Contributions à la flore fossile du Portugal: Lisbon. Comunicações dos Trabalhos do Serviços Geológicos de Portugal Lisbon series 4. Section des Travaux Geologiques du Portugal, Lisbon, $51 \mathrm{p}$.

Henkel, J.B., and Hochstetter, W. 1865. Synopsis der Nadelhölzer, deren charakteristischen Merkmale nebst Andeutungen über ihre Cultur und Ausdauer in Deutschlands Klima. J.G. Cottaschen Buchhandlung, Stuttgart, $446 \mathrm{p}$.
Hickey, L.J. 1973. Classification of the architecture of Dicotyledonous leaves. American Journal of Botany 60: 17-33.

Hickey, L.J., and Wolfe, J.A. 1975. The bases of angiosperm phylogeny: vegetative morphology. Annals of the Missouri Botanical Garden 62: 538-589.

Horaninow, P.F. 1834. Primae Lineae Systematis Naturae, nexui naturali omnium evolutionique progressivae per nixus reascendentes superstructi. Karoli Krajanis, St. Petersburg, 45 p.

Huber, B.T., Hodell, D.A., and Hamilton, C.P. 1995. Middle-Late Cretaceous climate of the southern high latitudes: Stable isotopic evidence for minimal equator-to-pole thermal gradients. Geological Society of America Bulletin 107: 1164-1191.

Hünicken, M. 1995. Floras Cretácicas y Terciarias. In: P. Stipanicic, and M.A. Hünicken (Eds.), Revisión y Actualización de la obra Paleobotánica de Kurtz en la República Argentina. Actas 11. Academia Nacional de Ciencias, Córdoba, p. 199-220.

Iglesias, A., Zamuner, A.B., Poiré, D.G., and Larriestra, F. 2007. Diversity, taphonomy and palaeoecology of an angiosperm flora from Cretaceous (Cenomanian-Coniacian) in southern Patagonia, Argentina. Palaeontology 50: 445-466.

Johnson, K.R. 1989. [A high resolution megafloral biostratigraphy spanning the Cretaceous-Tertiary boundary in the northern Great Plains. Ph.D. thesis, Connecticut Yale University, New Haven, 556 p. Unpublished.].

Jussieu de, A.L. 1789. Genera plantarum ordines naturales disposita. Herissant \& Barrois, Paris, 498 p.

Kaulfus, G.F. 1827. Das Wesen der Farrenkräuter Besonders Ihrer Fruchttheile Zugleich mit Rücksicht aauf Systematische Anordnung Betrachtet und mit Einer Darstellung der Entwicklung der Pteris serrulata aus dem Samen Begleitet. Erste Hälfte. Rey Carl Cnobloch, Leipzig, $119 \mathrm{p}$.

Keating, J.M. 1992. Palynology of the Lachman Crags Member, Santa Marta Formation (Upper Cretaceous) of northwest James Ross Island. Antarctic Science 4: 293-304.

Kendall, M.W. 1949. A Jurassic member of the Araucariaceae. Annals of Botany 13: 151-161.

Kirchner, E.D.M. 1831. Oder, Kurze Naturgeschichte der Pflanzen Überhaupt. Schul-Botanik 109: 13-20.

Koch, K.H.E. 1873. Bäume, Sträucher und Halbsträucher, welche in Mittel- und Nord-Europa im Freien kultivirt werden. Dendrologie 2, F. Enke, Erlagen, $424 \mathrm{p}$.

Kvaček, J. 2014. Marattiopsis vodrazkae sp. nov. (Marattiaceae) from the Campanian of the Hidden Lake Formation, James Ross Island, Antarctica. Acta Musei Nationalis Pragae 70: 211-218.

Kvaček, J., and Sakala, J. 2011. Late Cretaceous flora of James Ross Island (Antarctica) - preliminary report. Czech Polar Reports 1: 96-103.

Kvaček, J., Dašková, J., and Renáta, P. 2006. A new schizaeaceous fern, Schizaeopsis ekrtii sp. nov., and its in situ spores from the Upper Cretaceous (Cenomanian) of the Czech Republic. Review of Palaeobotany and Palynology 140: 51-60.

Laubenfels, D.J. de 1953. The external morphology of coniferous leaves. Phytomorphology 1: 1-20.

Lehmann, J.G.C. 1834. De plantis Cycadeis praesertim Africae australis. Novarum et Minus Cognitarum Stirpium. J.A. Meissner, Hamburg, $16 \mathrm{p}$.

Link, H.F. 1833. Enumeratio Plantarum Horti Regii Berolinensis Altera. G. Reimer, Berlin, $478 \mathrm{p}$.

Linnaeus, C. 1753. Species Plantarum. Laurentii Salvii, Stockholm, $1200 \mathrm{p}$.

Linnaeus, C. 1763. Ätliga frukter (Fructus esculenti): akademisk avhandling under Linnés presidium. A. Boerman and T. Fredbärj, Uppsala, 24 p. 
Macdondald, I.M., Barker, P.F., Garrett, S.W., Ineson, J.R., Pirrie, D., Storey, B.C., Whitham, A.G., Kinghorn, R.R.F., and Marshall, E.A. 1988. A preliminary assessment of the hydrocarbon potential of the Larsen Basin, Antarctica. Marine and Petroleum Geology 5: 34-53.

Manchester, S.R. 1994. Fruits and seeds of the Middle Eocene Nut Beds Flora, Clarno Formation, Oregon. Palaeontographica Americana 58: 1-205.

Marenssi, S.A., Salani, F., and Santillana, S. 2001. Geología de Cabo Lamb, Isla Vega, Antártida. Contribución Científica del Instituto Antártico Argentino 530: 1-43.

Martínez, L.C.A., Artabe, A.E., and Bodnar, J. 2012. A new cycad stem from the Cretaceous in Argentina and its phylogenetic relationships with other Cycadales. Botanical Journal of the Linnean Society 170: 436-458.

McArthur, J.M., Brame, J.A., and Thirlwall, M.F. 2000. Definition of the Late Cretaceous stage boundaries in Antarctica using strontium isotope stratigraphy. Journal of Geology 108: 623-640.

Miller, K.G., Wright, J.D., and Browning, J.V. 2005. Visions of ice sheets in a greenhouse world. Marine Geology 217: 215-231.

Miquel, F.A.W. 1842. Monographia Cycadearum. R. Natan, Utrecht, $82 \mathrm{p}$.

Nangalinum, N.S., and Cantrill, D.J. 2015. The Albian fern flora of Alexander Island, Antarctica. Cretaceous Research 55: 303-330.

Norstog, K.J., and Nicholls, T.J. 1997. The Biology of the Cycads. Cornell University Press, Ithaca, $363 \mathrm{p}$.

Olivero, E.B. 1992. Asociaciones de ammonites de la Formación Santa Marta (Cretácico tardío), Isla James Ross, Antártida. In: C.A. Rinaldi (Ed.), Geología de la Isla James Ross. Instituto Antártico Argentino, Buenos Aires, p. 47-76.

Olivero, E.B. 2012. Sedimentary cycles, ammonite diversity and palaeoenvironmental changes in the Upper Cretaceous Marambio Group, Antarctica. Cretaceous Research 34: 348-366.

Olivero, E.B., Ponce, J.J., and Martinioni, D.R. 2008. Sedimentology and architecture of sharp-based tidal sandstones in the Upper Marambio Group, Maastrichtian of Antarctica. Sedimentary Geology 210: 11-26.

Olivero, E.B., Scasso, R.A., and Rinaldi, C.A. 1986. Revision of the Marambio Group, James Ross Island, Antarctica. Contribuciones del Instituto Antártico Argentino 331: 1-28.

Panti, C., Césari, S.N., Marenssi, S.A., and Olivero, E.B. 2007. A new araucarian fossil species from the Paleogene of southern Argentina. Ameghiniana 44: 215-222.

Persoon, C.H. 1820. O Přirozenosti Rostlin aneb rostlinár. Jan Svatopluk Pres, Prague, $262 \mathrm{p}$.

Piper, A.T. 1988. [A preliminary palynological investigation into the Cretaceous strata of north-west James Ross Island and Vega Island, Antarctic Peninsula. M.Sc. dissertation, University of Sheffield, Sheffield, 81 p. Unpublished.].

Pirrie, D., and Marshall, J.D. 1990. High-palaeolatitude Late Cretaceous palaeotemperatures: new data from James Ross Island, Antarctica. Geology 18: 31-34.

Pirrie, D.P., Crame, J.A., Lomas, S.A., and Riding, J.B. 1997. Late Cretaceous stratigraphy of the Admiralty Sound region, James Ross Basin, Antarctica. Cretaceous Research 18: 109-137.

Platt, K.A., and Thomson, W.W. 1992. Idioblast oil cells of avocado: Distribution, isolation, ultrastructure, histochemistry, and biochemistry. International Journal of Plant Sciences 153: 301-310.

Poole, I., and Cantrill, D.J. 2006. Cretaceous and Cenozoic vegetation of Antarctica integrating the fossil wood record. In: J.E. Francis, D. Pirrie, and J.A. Crame (Eds.). Cretaceous-Tertiary High Latitude Paleoenvironments, James Ross Basin, Antarctica. Geological
Society of London Special Publication 258, London, p. 63-81.

Poole, I., and Francis, J.E. 1999. The first record of fossil atherospermataceous wood from the upper Cretaceous of Antarctica. Review of Palaeobotany and Palynology 107: 97-107.

Poole, I., and Francis, J.E. 2000. The first record of Winteraceae wood from the Cretaceous of Antarctica. Annals of Botany 85: 307-315.

Poole, I., and Gottwald, H. 2001. Monimiaceae sensu lato, an Element of Gondwanan Polar Forests: Evidence from the Late Cretaceous-Early Tertiary Wood Flora of Antarctica. Australian Systematic Botany 14: 207-230.

Poole, I., Cantrill, D.J., Hayes, P., and Francis, J.E. 2000a. The fossil record of Cunoniaceae: new evidence from Late Cretaceous fossil wood of Antarctica? Review of Palaeobotany and Palynology 111: 127-144.

Poole, I., Richter, H.G., and Francis, J.E. 2000b. Gondwanan origins for Sassafras (Lauraceae): evidence from Late Cretaceous fossil wood of Antarctica. International Association of Wood Anatomists Journal 21: 463-475.

Presl, C. 1938. Versuch einer geognostisch-botanischen Darstellung der Flora der Vorwelt. Chritoph Ernst Brenck's, Wittwe, 203 p.

Rees, P.M., and Smellie, J.L. 1989. Cretaceous angiosperms from an allegedly Triassic flora at Williams Point, Livingston Island, South Shetland Islands. Antarctic Science 1: 239-248.

Regel, E.A. 1857. Zwei [sic] neue Cycadeen, die im Botanischen Garten zu Petersburg kultivirt werden, nebst Beiträge zu Kenntniss dieser Familie. Bulletin de la Société Impériale des Naturalistes de Moscou 30: 163-191.

Reguero, M., Goin, F., Acosta Hospitaleche, C., Dutra, T., and Marenssi, S. 2013. Late Cretaceous/Paleogene West Antarctica terrestrial biota and its intercontinental affinities. Springer Briefs in Earth System Sciences, Berlin, 120 p.

Riding, J.B., and Crame, J.A. 2002. Aptian to Coniacian (Early-Late Cretaceous) palynostratigraphy of the Gustav Group, James Ross Basin, Antarctica. Cretaceous Research 23: 739-760.

Royer, D.L., Colin, C.P., and Beerling, D.J. 2005. Contrasting seasonal patterns of carbon gain in evergreen and deciduous trees of ancient polar forests. Paleobiology 31: 141-150.

Sakala, J., and Vodrážka, R. 2014. A new species of Antarctoxylon: a contribution to the early angiosperm ecosystem of Antarctica during the late Cretaceous. Antarctic Science 26: 371-376.

Scasso, R.A., Olivero, E.B., and Buatois, L.A. 1991. Lithofacies, biofacies and ichnoassemblage evolution of a shallow submarine volcaniclastic fan-shelf depositional system (Upper Cretaceous, James Ross Island, Antarctica). Journal of South American Earth Sciences 4: 239-260.

Schimper, W.P. 1869. Traité de Paléontologie Végétale. Baillière, Paris, 1, $674 \mathrm{p}$.

Seward, A.C. 1917. Fossil Plants, Volume III. Cambridge University Press, Cambridge, $656 \mathrm{p}$.

Smith, J.E. 1793. Tentamen botanicum de filicum generibus dorsiferarum. Mémoires de l'Academie Royale des Sciences 5: 401-422.

Smith, J. 1841. On Hewardia, a new genus of ferns. Journal of Botany, being a second series of the Botanical Miscellany 3: 431-433.

Smith, A.R., Pryer, K.M., Schuettpelz, E., Korall, P., Schneider, H., and Wolf, P.G. 2006. A classification for extant ferns. Taxon 55: 705-731.

Stockey, R.A., and Taylor, T.N. 1978. Cuticular features and epidermal patterns in the genus Araucaria de Jussieu. Botanical Gazette 139: 490-498.

Swartz, 0. 1801. Genera et species filicum. Journal für die Botanik 2: 3-120. 
Swenson, U., Hill, R.S., and McLoughlin, S. 2000. Ancestral area analysis of Nothofagus (Nothofagaceae) and its congruence with the fossil record. Australian Systematic Botany 13: 469-478.

Taylor, A.S., Haynes, J.L., and Holzman, G. 2008. Taxonomical, nomenclatural and biogeographical revelations in the Zamia skinneri complex of Central America (Cycadales: Zamiaceae). Botanical Journal of the Linnean Society 158: 399-429.

Tiffney, B.H. 1984. Seed size, dispersal syndromes, and the rise of the angiosperms: Evidence and hypothesis. Annals of the Missouri Botanical Garden 71: 551-576.

Whelanm, N.A. 1989. [A palynological investigation of samples from the Santa Marta Formation (Late Cretaceous) north-west James Ross Island, Antarctica. M.Sc. dissertation, University of Sheffield, Sheffield, 101 p. Unpublished.].

Whitham, A.G., Inneson, J.R., and Pirrie, G.D. 2006. Marine volcanoclastics of the Hidden Lake Formation (Coniacian) of James Ross Island, Antarctica: an enigmatic element in the history of a back-arc basin. In: J.E. Francis, D. Pirrie, and J.A. Crame (Eds.), Cretaceous-Tertiary high-latitude palaeoenvironments, James Ross Basin, Antarctica. Geological Society London Special Publications 258, London, p. 21-47.
Zijlstra, G., and van Konijnenburg-van Cittert, H. 2000. Proposal to Conserve the Name Araucarites C. Presl (Fossil Gymnospermae, Coniferales, Araucariaceae) against Araucarites Endl. (Fossil Gymnospermae, Coniferales). Taxon 48: 279-280.

doi: 10.5710/AMGH.17.02.2016.2930

Submitted: June $30^{\text {th }}, 2015$

Accepted: February $17^{\text {th }}, 2016$ 